\title{
GIS dan Pengaduan Perlengkapan Jalan Raya (SIGRA) DISHUB Kabupaten Tegal
}

\author{
Husni Faqih ${ }^{1}$, Zanuar Rifai ${ }^{2}$, Hilda Faiqoturrohmah ${ }^{3}$ \\ ${ }^{1,3}$ Universitas Bina Sarana Informatika \\ ${ }^{2}$ Universitas AMIKOM Purwokerto \\ Indonesia \\ E-mail:husni.hnf@bsi.ac.id
}

\begin{abstract}
:
The Department of Transportation (DISHUB) of Tegal Regency as the organizer of the highway has difficulties in monitoring road equipment due to the small number of personnel with a fairly large work area. Complaints by the public regarding maintenance of road equipment such as lacking or damaged road equipment are needed by DISHUB as input to be more effective and quick in collecting road equipment data. The main objective of this research is to create alternative solutions that can help DISHUB in maintaining road equipment. Data collection techniques by observation, interview, and literature study. The Extreme Programming method is used as a software development method. The results of this research are the Geographical Information System of the Highway that can be utilized by DISHUB of Tegal Regency and the general public who can provide information on the location of road equipment, as well as road equipment complaints services.
\end{abstract}

\section{Keywords:}

\section{GIS; Geographic Information System; Extreme Programming}

\section{Abstrak:}

Dinas Perhubungan (DISHUB) Kabupaten Tegal selaku penyelenggara jalan raya memiliki kesulitan pada pemantauan perlengkapan jalan raya dikarenakan jumlah personil yang sedikit dengan area kerja yang cukup luas. Aduan oleh masyarakat terkait pemeliharaan perlengkapan jalan raya seperti perlengkapan jalan yang kurang atau rusak dibutuhkan oleh DISHUB sebagai masukan supaya lebih efektif dan cepat dalam pendataan perlengkapan jalan raya. Tujuan utama penelitian ini adalah membuat alternatif solusi yang dapat membantu DISHUB dalam pemeliharaan perlengkapan jalan raya. Teknik pengumpulan data dengan observasi, wawancara, dan studi pustaka. Metode Extreme Programming digunakan sebagai metode pengembangan perangkat lunak. Hasil dari penelitian adalah Sistem Informasi Geografis Jalan Raya yang dapat dimanfaatkan oleh DISHUB Kabupaten Tegal dan masyarakat umum yang dapat memberikan informasi titik lokasi perlengkapan jalan, serta layanan pengaduan perlengkapan jalan raya.

\section{Kata Kunci:}

Sistem Informasi Geografis; GIS (Geographic Information System); Extreme Programming 


\section{Introduction}

Sesuai dengan (UURI Nomor 22, 2009) yang mensiratkan bahwa keselamatan, keamanan, kelancaran, dan ketertiban lalu lintas dan angkutan jalan merupakan tugas dari penyelenggara jalan. Untuk mencapai hal tersebut maka ketersediaan perlengkapan jalan yang memadai sangat berperan penting, dalam hal ini merupakan salah satu tugas dari Dinas Perhubungan (DISHUB). Terdapat masalah bahwa DISHUB Kabupaten Tegal kesulitan dalam memantau titik rambu lalu lintas yang tersebar di wilayah Kabupaten Tegal dengan luas area 87.879 Ha yang terbagi menjadi 18 Kecamatan [2]. Sedikitnya jumlah personil perlengkapan jalan mempengaruhi kinerja DISHUB dalam memberikan layanan perlengkapan jalan yang layak. Kurangnya sosialisasi kepada masyarakat terkait aduan perlengkapan jalan pun menjadi masalah umum, sehingga kurangnya informasi aduan menyebabkan kinerja DISHUB dalam pemeliharaan perlengkapan jalan kurang maksimal.

Terdapat 3 penelitian sebelumnya yang berhubungan dengan penelitian ini. Penelitian pertama dari [3] yang meneliti tentang sensus industri di Kabupaten Tegal yang mana masyarakat kurang informasi terkait data tersebut dikarenakan data tersentral di Badan Pusat Statistik (BPS). Menanggapi hal tersebut peneliti membangun sistem informasi geografis yang mampu memberikan informasi terkait profil, peta, dan lokasi industri, hingga nilai investasinya di wilayah Kabupaten Tegal. Pengguna yang dapat menginput data di Sistem Informasi Geografis ini adalah admin dan petugas DISHUB, masyarakat adalah pengunjung aplikasi yang mendapatkan informasi. Penelitian kedua dari [4] yang meneliti tentang kesulitan dari masyarakat (customer) pencari perumahan di Kabupaten Tasikmalaya karena pada saat itu data perumahan di Kabupaten Tasik Malaya tidak terdata dengan baik dan kurangnya fasilitas penyedia informasi perumahan ke masayrakat. Peneliti membuat Sistem Informasi Geografis dimana admin aplikasi dapat mendata perumahan di Tasikmalaya sehingga masyarakat pengguna aplikasi dapat mendapatkan informasi lokasi dan koordinat perumahan yang sudah terdata. Penelitian ketiga dari [5] yang meneliti tentang penyebaran informasi pendidikan (sekolahsekolah) di Kecamatan Tugu Kota Semarang. Observasi menghasilkan data bahwa masyarakat kurang mendapatkan informasi sekolah-sekolah di Kecamatan Tugu dan terdapat kesulitan mengakses informasi terbaru yang mana data tersebut hanya terdapat di Dinas Pendidikan Kota Semarang. Peneliti membuat Sistem Informasi Geografis untuk membantu 
masyarakat dalam mendapatkan informasi lengkap terkait sekolah-sekolah yang ada di Kecamatan Tugu mulai dari peta, lokasi, hingga informasi umum sekolah tersebut. Dari ketiga penelitian tersebut para peneliti berfokus pada pembuatan Sistem Informasi Geografis yang pengguna utamanya adalah admin dari dinas terkait, masyarakat umum hanya sebagai pengunjung penerima informasi. Oleh karena itu dalam penelitian ini selain membangun Sistem Informasi Geografis Jalan Raya yang dapat memberikan informasi terkait lokasi dan kondisi dari perlengkapan jalan raya, peneliti juga memberikan fasilitas kepada masyarakat untuk memberikan aduan terkait perlengkapan jalan raya yang membuat terterjadinya simbiosis mutualisme antara masyarakat dan DISHUB Kabupaten Tegal. Sehingga diharapkan tujuan utama penelitian tercapai, yaitu membuat alternatif solusi yang dapat membantu DISHUB dalam pemeliharaan perlengkapan jalan raya

\section{Materials and Methods}

\subsection{Materials}

Alat dan bahan penelitian adalah segala sesuatu yang dapat digunakan dalam pengumpulan data. Bahan penelitian berupa User Stories yang didapatkan dari tahapan eksplorasi metode Extreme Programming. Sedangkan alat penelitian yang digunakan antara lain ER-Diagram untuk desain database, Usecase Diagram untuk desain sistem secara behaviour, dan Blackbox Testing untuk pengujian unit.

\subsection{Methods}

\subsubsection{Teknik Pengumpulan Data}

Penelitian menggunakan teknik pengumpulan data oleh Wijaya dan Sari dalam [6], sebagai berikut:

1. Observasi

Observasi pada Dinas Perhubungan Kabupaten Tegal untuk mendapatkan data dan titik lokasi perlengkapan jalan yang ada di Kabupaten Tegal.

2. Wawancara

Wawancara dengan narasumber Koordinator bagian perlengkapan jalan raya untuk mendapatkan data perlengkapan jalan raya, permasalahan yang sering dihadapi, dan solusi-solusi yang sudah dilakukan.

3. Studi Pustaka

Mencari referensi dari publikasi ilmiah yang bertema Sistem Informasi Geografis dan metode pengembangan sistem Extreme Programming.

\subsubsection{Metode Pengembangan Software}

Metode Extreme Programming (XP) yang merupakan bagian dari metode Agile diunakan sebagai teknik pengembangan software. Metode Extreme Programming dipilih karena termasuk metode 
pengembangan software yang cepat, dan efisien serta fleksibel sesuai kebutuhan stakeholder. Extreme Programming digunakan untuk meningkatkan kualitas perangkat lunak yang responsif terhadap perubahan kebutuhan pelanggan [7]. Sedangkan Agile lebih ke pendekatan yang iterative dan evolusioner dengan mengedepankan kolaborasi dan penggunaan dokumen formal terbatas yang tepat untuk membangun perangkat lunak yang berkualitas dalam hal biaya serta waktu yang sesuai dengan kebutuhan stakeholder yang dapat berubah-ubah [8].

Inti pokok XP memiliki empat nilai dasar sesuai yang dikemukakan oleh Jefriess RE di dalam Chandra Ramdhani dkk. [9], antara lain Communication, Simplicity, Feedback, dan Courage.

Tahapan Extreme Programming [9], antara lain:

\section{Tahap Eksplorasi}

Tahapan mencari kebutuhan dasar sistem dari customer yang dituliskan ke dalam User Stories. Dokumentasi visi dan ruang lingkup pekerjaan merupakan hasil dari tahapan eksplorasi.

2. Tahap Perencanaan

Berorientasi terhadap tahap eksplorasi. Tahap perencanaan membuat perkiraan pada kebutuhan bisnis, kebutuhan sistem dan kebutuhan pengguna. Penjadwalan yang menggambarkan perencanaan pembangunan sistem adalah hasil dari tahap perencanaan.

3. Tahap Iterasi Pengembangan Sistem Terdapat sub tahapan seperti analisa sistem, desain sistem, pembangunan sistem, dan uji unit akan melakukan iterasi berulang hingga uji unit sukses.

4. Tahap Produksi Akhir

Sistem selesai dan siap diluncurkan dan melakukan uji sistem secara keseluruhan. Untuk lebih jelasnya, skema dari metode Extreme Programming dapat dilihat pada Gambar 1 [10].

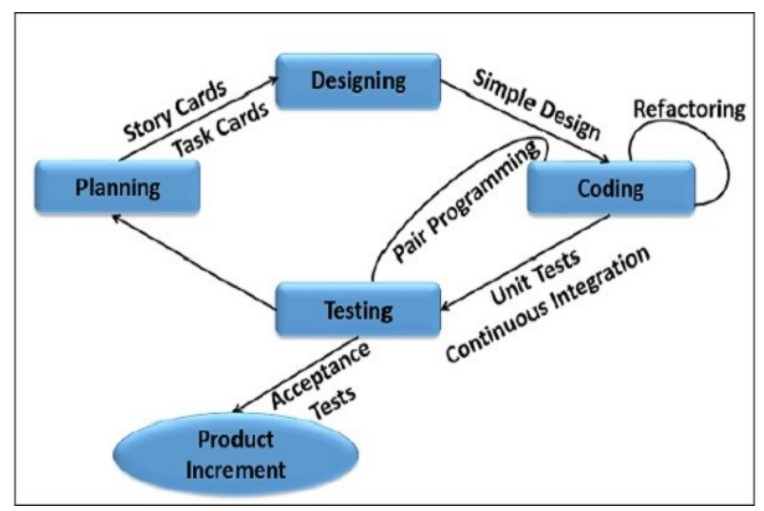

Sumber: Chandra Ramdhani (2019)

Gambar 1. Skema Extreme Programming

\section{Results and Discussion}

Hasil dan pembahasan akan menyesuaikan dari skema Extreme Programming yang terdiri atas Planning, Designing, Coding, Testing, dan Product Increment.

\subsection{Planning}

Story Cards yang berisi kebutuhan dasar sistem hasil dari tahap eksplorasi menjadi 
salah satu bahan untuk tahap perencanaan (planning) pembuatan sistem di pihak manajemen. Di tahap ini saah satunya menghasilkan daftar kebutuhan pengguna. Aplikasi SIGRA memiliki 3 pengguna yang saling berinteraksi dalam sistem, yaitu Admin, Member, dan Pengunjung yang memiliki kebutuhan masing-masing sebagai berikut:

\section{Pengunjung}

a. Pengunjung dapat mengakses fasilitas umum pada aplikasi seperti beranda, tentang, kontak, cari perlengkapan dan artikel.

b. Pengunjung dapat melakukan registrasi akun.

2. Member

a. Member dapat memiliki fasilitas umum Pengunjung.

b. Member dapat melakukan login untuk masuk ke sistem.

c. Member dapat mengelola profile.

d. Member dapat membuat pengaduan perlengkapan jalan raya dan melihat history-nya.

\section{Admin}

a. Admin dapat melakukan login untuk masuk ke sistem.

b. Admin dapat mengelola manajemen user, data kategori, data perlengkapan jalan, data pengaduan, data artikel, laporan dan grafik perlengkapan jalan, dan laporan pengaduan.

\subsection{Designing}

Tahap Designing termasuk dalam kategori Iterasi Pengembangan Sistem. Tahap ini menghasilkan desain database dengan ER-Diagram dan desain sistem dengan Usecase Diagram.

\section{Usecase Diagram}

Usecase Diagram yang memperlihatkan tingkah laku pengguna dalam sistem dapat dilihat di Gambar 2.

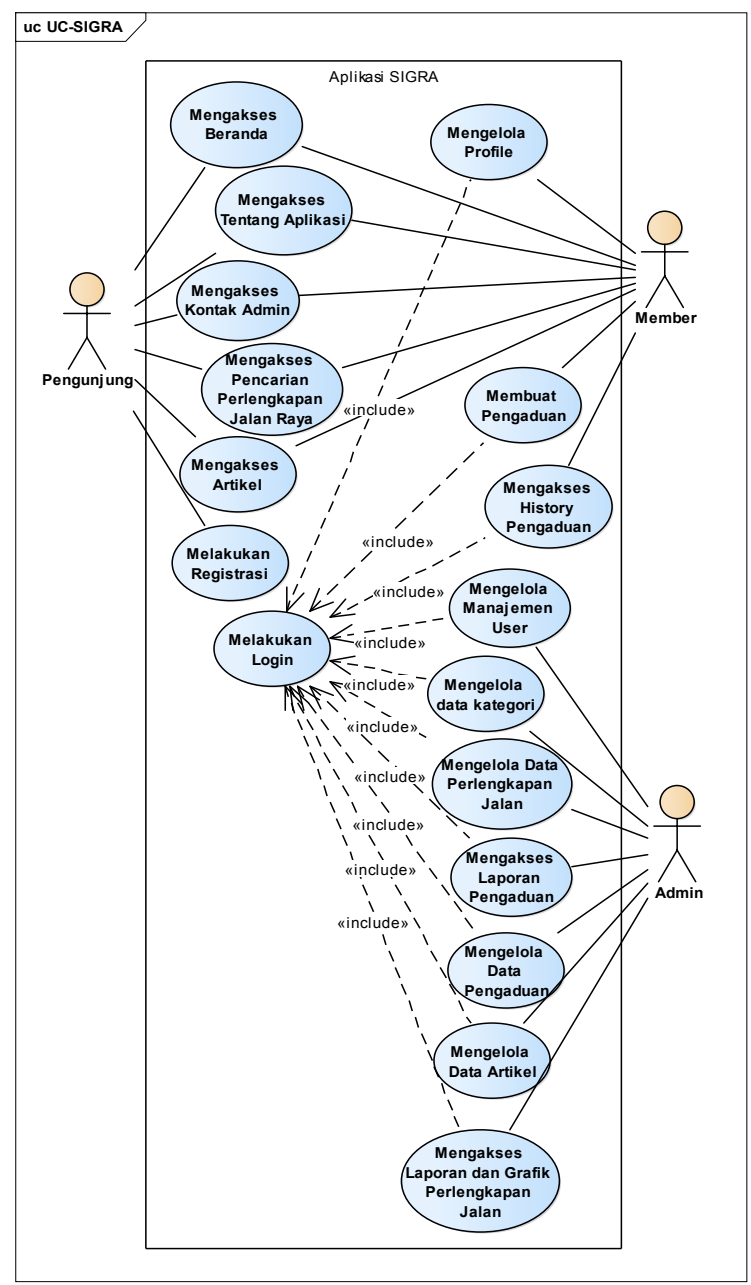

Sumber: Hasil Penelitian (2020)

Gambar 2. Usecase Diagram SIGRA

\section{ER-Diagram}

ER-Diagram untuk desain database yang digunakan dalam aplikasi SIGRA dapat 
dilihat di Gambar 3.

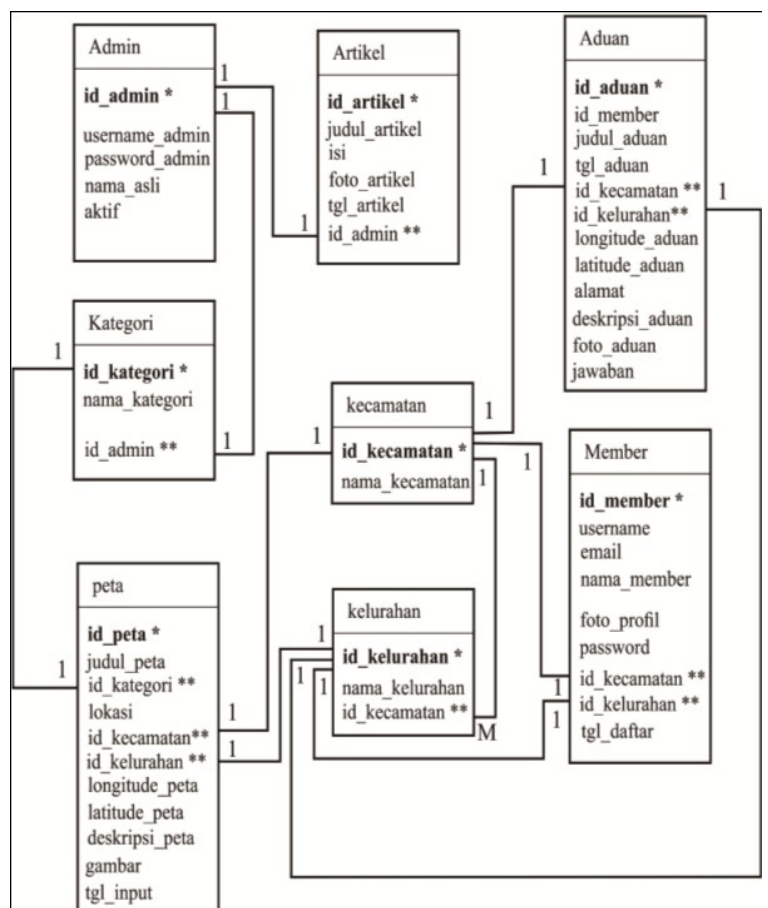

Sumber: Hasil Penelitian (2020)

Gambar 3. ERD Database SIGRA

\subsection{Coding}

Tahap Coding juga masuk dalam kategori Iterasi Pengembangan Sistem. Di tahap ini akan menghasilkan unit-unit program yang nantinya akan dilakukan uji unit hingga tiap unit program dapat bekerja dengan baik. Berikut adalah hasil implementasi tiap unitnya, antara lain:

1. Implementasi Unit Akun Pengunjung

\section{a. Beranda Pengunjung}

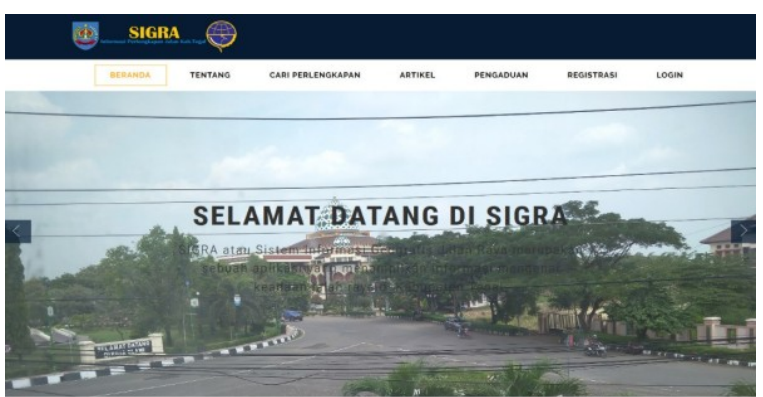

Sumber: Hasil Penelitian (2020)

Gambar 4. Page Beranda Pengunjung b. Pencarian Perlengkapan Jalan

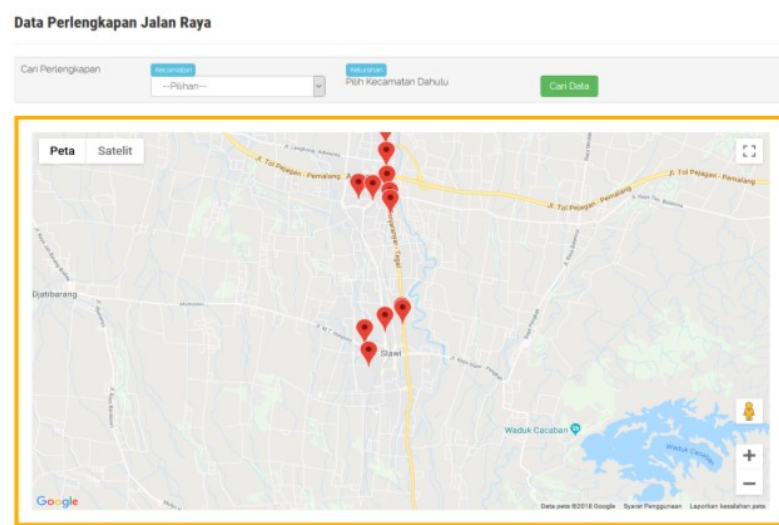

Sumber: Hasil Penelitian (2020)

Gambar 5. Pencarian Perlengkapan Jalan c. Registrasi Member

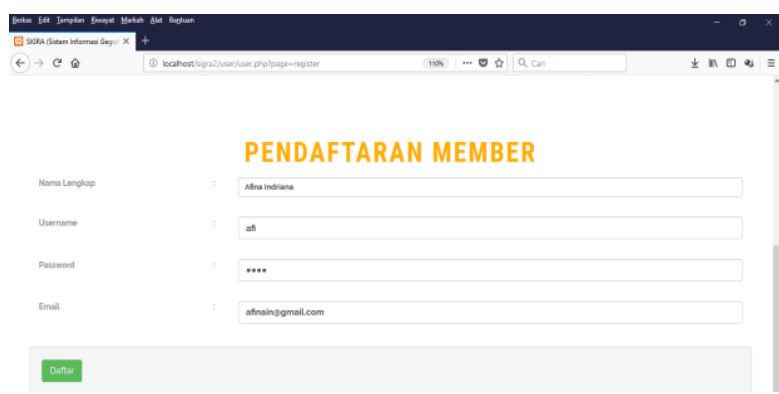

Sumber: Hasil Penelitian (2020)

Gambar 6. Page Registrasi Member

2. Implementasi Unit Akun Member

a. Page Login

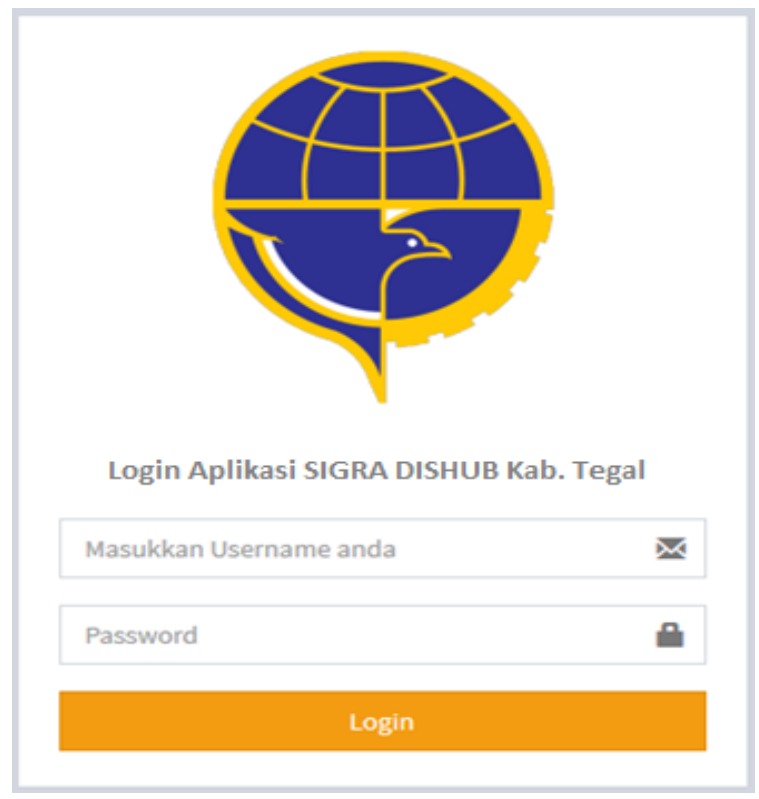

Sumber: Hasil Penelitian (2020)

Gambar 7. Page Login 
b. Page Pengaduan

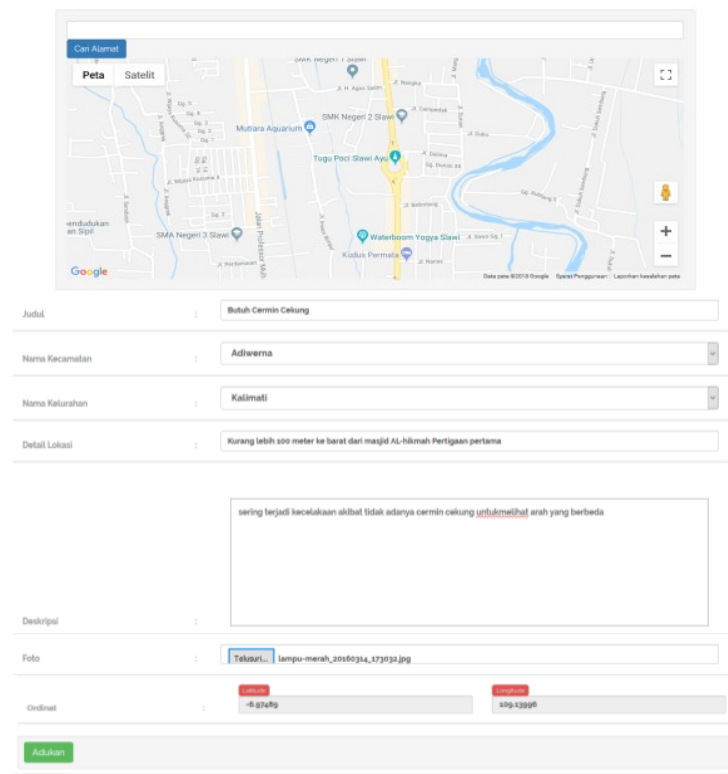

Sumber: Hasil Penelitian (2020)

Gambar 8. Page Pengaduan

c. Page History Pengaduan

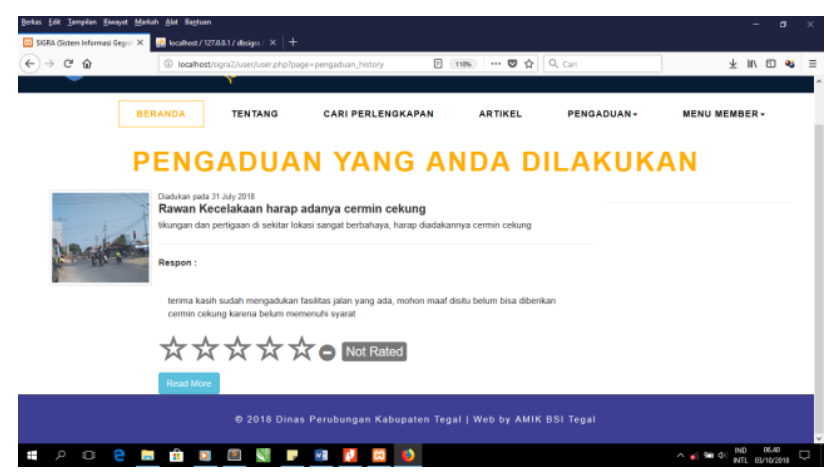

Sumber: Hasil Penelitian (2020)

Gambar 9. Page History Pengaduan

3. Implementasi Unit Akun Admin

a. Page Manajemen User

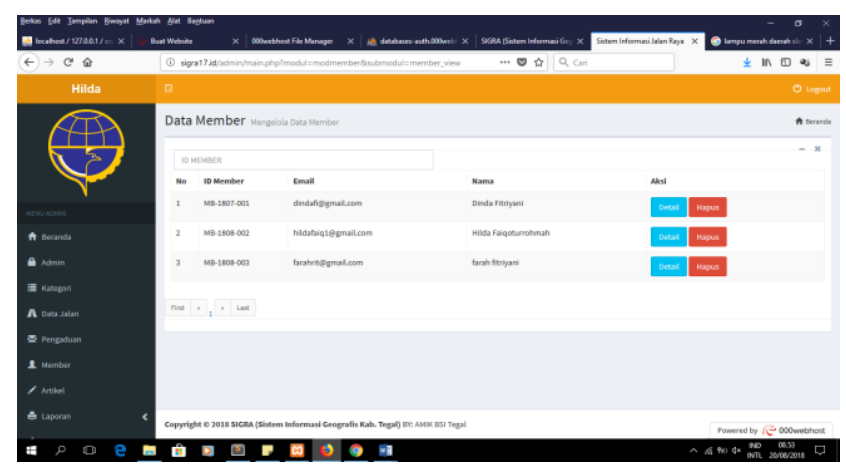

Sumber: Hasil Penelitian (2020)

Gambar 10. Page Manajemen User b. Page Data Pengaduan Member

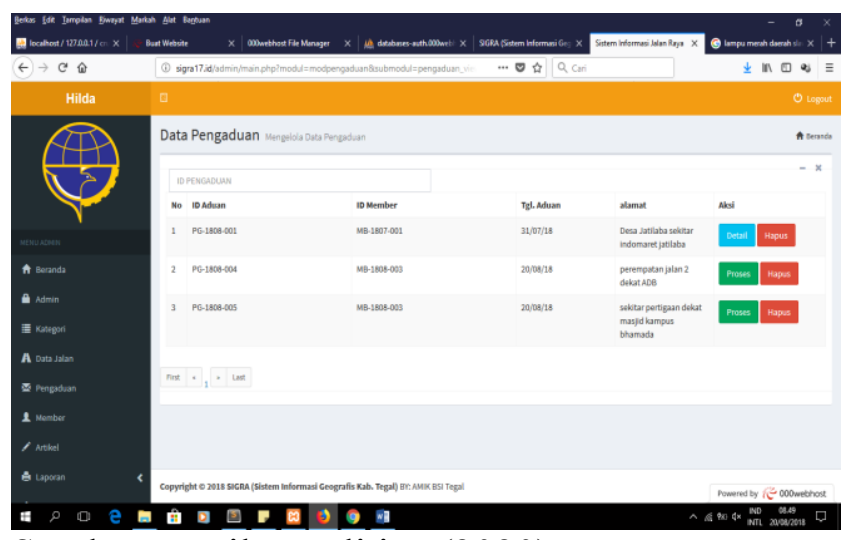

Sumber: Hasil Penelitian (2020)

Gambar 11. Page Data Pengaduan Member

c. Page Manajemen Perlengkapan Jalan

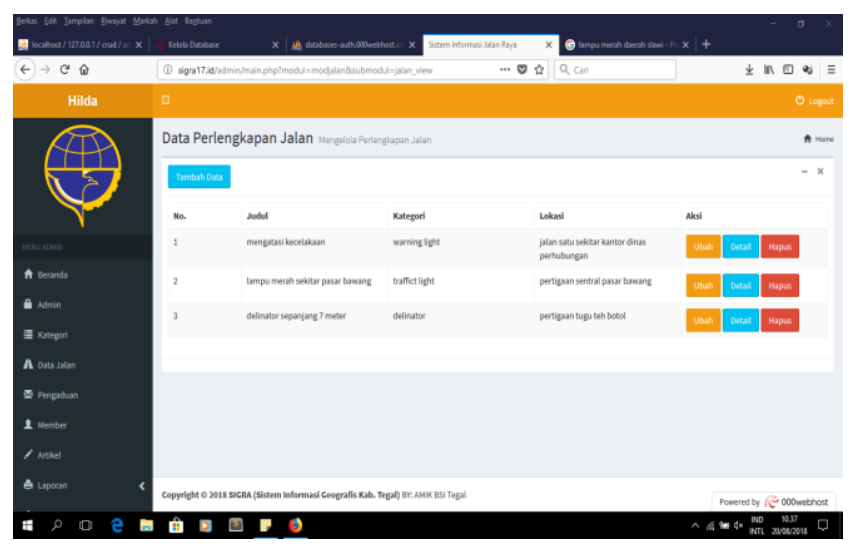

Sumber: Hasil Penelitian (2020)

Gambar 12. Page Data Perlengkapan Jalan

d. Page Laporan Grafik Perlengkapan Jalan

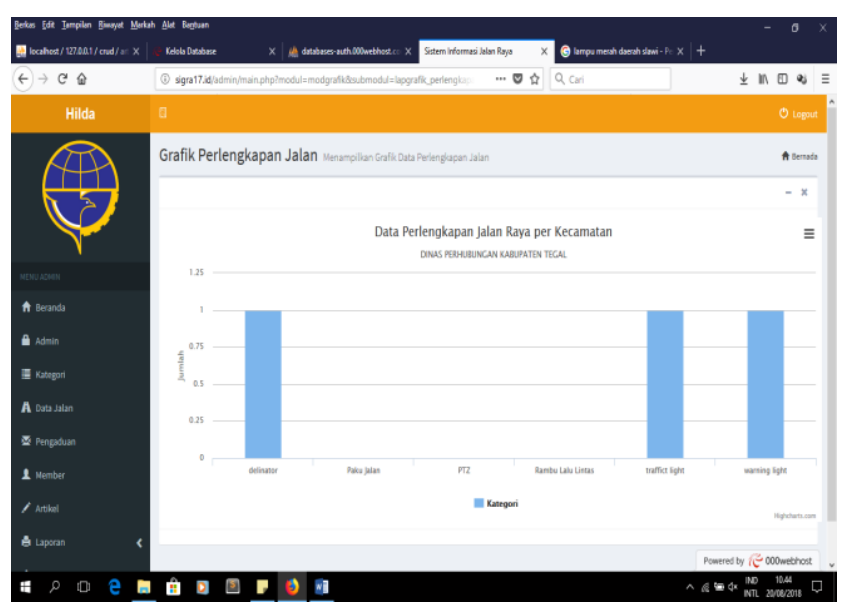

Sumber: Hasil Penelitian (2020)

Gambar 12. Page Laporan Grafik

Perlengkapan Jalan 


\subsection{Testing}

Tahap testing untuk menguji apakah aplikasi berjalan dengan baik. Blackbox Testing digunakan dalam pengujian ini. Sesuai dengan pembahasa dari Pressman bahwa BlackBox Testing digunakan pada pengujian sistem dengan fokus di kebutuhan fungsional software [11]. Perhatian pengujian dengan BlackBox Testing pada informasi domain, sehingga struktur kontrol diabaikan pada pengujian ini [12].

Tabel 1. Blackbox Testing Aplikasi SIGRA

\begin{tabular}{|c|c|c|c|c|}
\hline No & $\begin{array}{l}\text { Skenario } \\
\text { Pengujian }\end{array}$ & Test Case & $\begin{array}{ll}\text { Luaran } & \text { yang } \\
\text { diharapkan }\end{array}$ & Hasil \\
\hline 1 & $\begin{array}{l}\text { Pengunjung } \\
\text { mencari data } \\
\text { perlengkapan jalan }\end{array}$ & $\begin{array}{l}\text { Klik menu Cari } \\
\text { Perlengkapan } \\
\text { Jalan }\end{array}$ & $\begin{array}{l}\text { Tampil page } \\
\text { pencarian } \\
\text { perlengkapan jalan }\end{array}$ & Valid \\
\hline 2 & $\begin{array}{l}\text { Pengunjung } \\
\text { melakukan } \\
\text { registrasi member } \\
\text { dengan } \\
\text { lengkap }\end{array}$ & $\begin{array}{l}\text { Input data } \\
\text { member } \\
\text { lengkap }\end{array}$ & $\begin{array}{l}\text { Sistem akan mendata } \\
\text { member baru, ada } \\
\text { pesan selamat, dan } \\
\text { direct ke page login. }\end{array}$ & Valid \\
\hline 3 & $\begin{array}{l}\text { Member } \\
\text { melakukan login } \\
\text { dengan data benar }\end{array}$ & $\begin{array}{l}\text { Input username } \\
\text { dan password } \\
\text { yang sesuai }\end{array}$ & $\begin{array}{l}\text { Member berhasil } \\
\text { login, ada pesan } \\
\text { welcome, direct ke } \\
\text { page beranda } \\
\text { member }\end{array}$ & Valid \\
\hline 4 & $\begin{array}{l}\text { Member } \\
\text { menggunakan } \\
\text { fasilitas } \\
\text { pengaduan } \\
\text { perlengkapan jalan } \\
\text { dengan data } \\
\text { lengkap }\end{array}$ & $\begin{array}{l}\text { Input data } \\
\text { aduan } \\
\text { perlengkapan } \\
\text { jalan (lengkap) }\end{array}$ & $\begin{array}{l}\text { Pengaduan terdata, } \\
\text { pesan terimakasih, } \\
\text { direct ke pade } \\
\text { history pengaduan. }\end{array}$ & Valid \\
\hline 5 & $\begin{array}{l}\text { Admin monitoring } \\
\text { aduan } \\
\text { perlengkapan jalan }\end{array}$ & $\begin{array}{l}\text { Masuk ke } \\
\text { fasilitas Data } \\
\text { Pengaduan } \\
\text { Member }\end{array}$ & $\begin{array}{l}\text { Tampil seluruh data } \\
\text { pengaduan } \\
\text { perlengkapan jalan } \\
\text { raya, }\end{array}$ & Valid \\
\hline 6 & $\begin{array}{l}\text { Admin mengakses } \\
\text { Laporan dan } \\
\text { Grafik } \\
\text { perlengkapan jalan }\end{array}$ & $\begin{array}{l}\text { Masuk ke } \\
\text { fasilitas } \\
\text { Laporan dan } \\
\text { Grafik } \\
\text { perlengkapan } \\
\text { jalan }\end{array}$ & $\begin{array}{l}\text { Tampil laporan dan } \\
\text { grafik data } \\
\text { perlengkapan jalan }\end{array}$ & Valid \\
\hline
\end{tabular}

\subsection{Product Increment}

Tahap ini tidak dikerjakan karena aplikasi belum dirilis dan belum diterapkan di DISHUB Kabupaten Tegal.

\section{Conclusions}

Sistem Informasi Geografis pada umumnya dapat memberikan kemudahan kepada para pengguna untuk mencari lokasi dan koordinat suatu objek yang dituju. Aplikasi SIGRA yang termasuk bagian dari Sistem Informasi Geografis dapat menjembatani antara masyarakat dengan DISHUB Kabupaten Tegal dalam publikasi dan pencarian informasi perlengkapan jalan raya serta adanya simbiosis mutualisme melalui fasilitas pengaduan perlengkapan jalan raya. Dengan teknik Extreme Programming sangat mempermudah peneliti dalam membangun aplikasi SIGRA karena dapat melakukan pair programming dan terdapat iterasi pengembangan sistem yang memungkinkan proyek aplikasi dapat selesai dengan cepat dan efisien. Software hasil penelitian yang masih berupa aplikasi website saja. Sedangkan di era revolusi industri 4.0 ini penggunaan gadget smartphone sangat intens, sehingga diharapkan di penelitian selanjutnya dapat dikembangkan atau ditambahkan ke aplikasi mobile.

\section{References}

[1] UURI, "Undang Undang Republik Indonesia," 2009.

[2] BAPPEDA dan LITBANG Kabupaten Tegal, "Peta Wilayah Kabupaten Tegal," http://bappeda.tegalkab.go.id/, 
2020. [Online]. Available:

http://bappeda.tegalkab.go.id/?page_id

=14. [Accessed: 13-Feb-2020].

[3] G. W. Sasmito, "Penerapan Metode Waterfall Pada Desain Sistem Informasi Geografis Industri Kabupaten Tegal," J. Inform. Pengemb. IT, vol. 2, no. 1, pp. 6-12, 2017.

[4] I. A. Pratama and S. Purwidayanta, "Sistem Informasi Geografis Lokasi Perumahan Di Kabupaten Tasikmalaya Berbasis Web," Jumanka, vol. 02, no. 01, 2018.

[5] A. Basir and B. Hartono, "Sistem Informasi Geografis Bidang Pendidikan Pada Kecamatan Tugu Semarang," ELKOM, vol. 11, no. 2, pp. 43-55, 2018.

[6] H. Faqih, A. S. Islam, Z. Rifai, and A. A. A. S. W, "Desain Aplikasi Manajemen Kunjungan Pelanggan Barbershop Squad Corporation ( AKSQUAD )," IJSE - Indones. J. Softw. Eng., vol. 5, no. 2, pp. 22-33, 2019.

[7] I. K. Raharjana, Pengembangan Sistem Informasi Menggunakan Metode Agile, I, I. Yogyakarta: Deepublish, 2017.

[8] Yurindra, Software Engineering, 1st ed. Yogyakarta: Deepublish, 2017.

[9] E. Chandra Ramdhani, R. Ratnawati, and C. Daulika Nugraha, "Sistem Informasi Peminjaman Dan Pembayaran Kredit Usaha (SIPAPEDA) Menggunakan Model Extreme Programming (Study Kasus : DAPM Jembar Kabisa Babakancikao Purwakarta)," J. Inform. J. Pengemb. IT, vol. 4, no. 2, pp. 93-99, 2019.

[10]D. H. Pertiwi, "Metode extreme programming $(\mathrm{xp})$ pada website sistem informasi franchise $1 \mathrm{kp}$ palcomtech," $J$. Mikrotik, vol. 8, no. 1, pp. 86-98, 2018.

[11]A. S. and P. H. Y., Pengembangan Aplikasi Web GIS Pariwisata Backpacker, 1st ed, 1st ed. Yogyakarta: Deepublish, 2017.

[12]J. T. S., "Pengujian Aplikasi dengan Metode Blackbox Testing Boundary Value Analysis (Studi kasus: Kantor Digital Politeknik negri Lampung)," $J$. Pengemb. IT, vol. 3, no. 2, pp. 45-48, 2018. 